\title{
Screening of Natural Bacterial Flora of Pomegranate Roots (Punica granatum L.) and their Antibiotic Activity in Taif, Saudi Arabia
}

\author{
Ahmad F. Shahaby ${ }^{1,2 *}$, Abdulla A. Alharthi ${ }^{1}$ and Adel E. El Tarras ${ }^{1,2,3}$ \\ ${ }^{1}$ Biotechnology and Genetic Engineering Unit, College of Medicine, Taif University, \\ Taif, Saudi Arabia \\ ${ }^{2}$ Cairo University, College of Agriculture, Department of Microbiology, Genetics, Cairo, Egypt \\ ${ }^{3}$ Al-Saedan Research Chair for Genetic Behavioral Disorders, Saudi Arabia \\ *Corresponding author
}

\begin{abstract}
A B S T R A C T
Keywords

Pomegranate, isolation, Identification of bacteria, 16S-rRNA, Antibiotics, susceptibility, Fruit extracts.

Article Info

Accepted: 09 January 2016 Available Online: 10, February 2016

Taif region is situated in the central foothills of the Sarawat mountains at an altitude of 2200 to $2500 \mathrm{~m}$ above the sea level. Special type of pomegranate is cultivated there and called taify pomegranate. Therefore, exploring the types of microorganisms tolerant to root exudates is important. The objective of this study was to identify bacteria, actinomycetes and potential bacterial pathogens of pomegranate roots and their antimicrobial susceptibility patterns as well as effect of fruit parts extract on isolated bacteria. A total of 102 isolate were isolated and identified by morphological, physiological, APi profiles and 16S-rRNA techniques. Out of 102 isolated bacteria, from free soil 38 (37.3\%), rhizosphere 55(53.9\%) and inside roots 9(8.8\%). Isolated Actinomycetes represent 23 (22.5\%), Streptomyces 21 (20.6\%) and Sacchromyces cerevieace 5(4.9\%) of all isolated microorganisms. Isolates were identified as B. subtilis, S. cerevieace, S. pneumoniae, S. pyogenes, K. pneumoniae, A. baumannii, P. aerogenosa, A. chroococum, H. seropedicae, A. lipoferumand E.aerogenes. Susceptibility testing was done according to Clinical and Laboratory Standards Institute (CLSI) guideline. Tetracycline was effective against $75.5 \%$ of isolated pathogens. In general, Gram positive isolates were more susceptible to all antibiotic tested, whereas Gram negative isolates were less susceptible to all antibiotic tested. Antimicrobial activity of crude extracts of rind, fruit, and juice ofpomegranate fruitswere evaluated against 18Grampositiveand 35 Gram-negative bacteria. Crude alcoholic extracts of rind, seeds extract (juice) and whole fruit were evaluated against isolated Gram-positive and Gram-negative by agar disc diffusion method. All fruit parts were active against all tested bacteria (B. subtilis, E. aerogenes, $K$. pneumonia and $P$. aerogenosa), and moreover, against $\mathrm{N}_{2}$-Fixing bacteria (A. chroococcum, A.lipoferum and $H$. seropedicae). Rind extract was less active against $P$. aeruginosa, juice against $E$. aerogenes, whole fruit extract against $B$. subtilis. In general, juice (seed extract) was relatively more active than extracts of other parts of the fruit. The descending order of activity of the extracted parts of the plant fruit was juice, rind and whole fruit, respectively. On the other hand, Gram- positive bacteria, B. subtilis $S$. pneumoniae and A. chroococcum were more sensitive than Gram-negative and their inhibition zones. Therefore, it may be concluded that fruits of pomegranate extracts have broad spectrum antimicrobial activity and their activity could be attributed, to a great extent, to their contents of alkaloids and flavonoids.
\end{abstract}




\section{Introduction}

Taif is a city in the Mecca Province of Saudi Arabia at an elevation of $1,879 \mathrm{~m}(6,165 \mathrm{ft})$ on the slopes of the Sarawat Mountains. Al Shafa is a small village situated high upon the Sarawat Mountains at an elevation of 2200 to 2500 meters above sea level, rich in agricultural products. Pomegranate (Punica granatum L.) is one of the important fruit crops in arid and semi-arid regions. Taif especially, in Shafa area produce pomegranate and grapes as remarkable fruits. Panichayupakaranant et al. (2010) reported that pomegranate (Punica granatum L.) is an ancient and important fruit crop of subtropical and tropical regions of the world. Although native of Iran and adjoining areas, pomegranate has been widely cultivated throughout India and Mediterranean regions of Asia, Africa and Europe. India is the largest pomegranate growing (1.3 lakh ha) and producing (11 lakh tons) country of the world followed by Iran with an area of 56,239 ha and production of 7.05 lakh tons. Pomegranate (Punica granatum L.), a species of Punicaceae, has recently become of great interest to the scientists who engage themselves in pharmaceutical, nutriological and pharmacological research, and new drug development, due to its distinctive multiple officinal parts and multiple bioactivities such as hypolipidemic, antioxidant, antiviral, anti-neoplastic, antibacterial, antidiabetic, anti- diarrheal, and helminthic effects.

Kloepper 2003 and Bakker et al. 2007 reported that among PGPRs are representatives of the following genera: Acinetobacter, Agrobacterium, Arthrobacter, Azoarcus, Azospirillum, Azotobacter, Bacillus, Burkholderia, Enterobacter, Klebsiella, Pseudomonas, Rhizobium, Serratia, Azospirllium and
Thiobacillus. Some of these genera such as Azoarcus spp., Herbaspirillum and Burkholderia include endophytic species.

The pomegranate tree, which is said to have flourished in the Garden of Eden, has also been extensively used as a folk medicine in many cultures, documented at least as far back as the Egyptian Papyrus of Ebers, 50 B.C. (Wren, 1988). The most famous usage worldwide has been as a vermifugal or taenicidal agent (Zhicen, 1987; Kapoor, 1990), i.e., a killer and expeller of intestinal worms. According to one account, the alkaloids contained in the root, tree bark, and to a lesser extent, fruit rind, cause the "tapeworm to relax its grip on the wall of the intestine" thus allowing the weakened parasites to be easily expelled by a second herbal drug, one which is cathartic (Wren, 1988). The second major property of pomegranate hulls exploited in folk medicine is their strong astringency, making them a popular remedy throughout the world, in the form of an aqueous decoction (i.e., boiling the hulls in water for 10-40 minutes), for dysentery and diarrhea, and also for stomatitis (Boukef 1982; Caceres., 1987; Nagaraju and Rao, 1990). The decoction can be drunk, used as a mouthwash, douche or enema. Eating pomegranate regularly ensures optimal dental health as it destroys the bacteria responsible for causing formation of plaque.

Other ethnomedical explorations have documented pomegranate hull and/or root extract usage both orally and intravaginally to prevent fertility (Gujral et al.1960,Jochle, 1971) and abortion (Ramirez,1988) and to ameliorate assorted gynecological problems (Singh, 1980; Goh,1984). Other traditional uses of these materials have included treatments for snakebite (Jain and Puri 1984), diabetes (Singh 1986), burns (Siang 1983) and leprosy (Singh 1980). The fresh 
fruit itself has been used as a refrigerant to lower fever (Arseculeratne 1985).

Panichayupakaranant et al. (2010) studied antibacterial, anti-inflammatory and antiallergic activities of standardised pomegranate rind extract (SPRE) containing $13 \% \mathrm{w} / \mathrm{w}$ ellagic acid in vitro. The antibacterial activity of SPRE was determined using the disc diffusion and broth microdilution methods. SPRE exhibited a potent bacteriostatic effect against Propionibacterium acnes, a Grampositive anaerobe, with a MIC of $15.6 \mathrm{lg} / \mathrm{ml}$, and Gram positive facultative anaerobic bacteria, Staphylococcus aureus and Staphylococcus epidermidis, with MICs of 7.8-15.6 lg/ml. Anti-inflammatory activity of SPRE was evaluated by measuring the inhibition of nitric oxide (NO) production by murine macrophage-like RAW264.7 cells. SPRE exhibited a potent NO inhibitory effect, with an IC50 of $10.7 \mathrm{lg} / \mathrm{ml}$. Evaluation of the anti-allergic activity showed that SPRE inhibited the release of $b$ hexosaminidase from antigen-stimulated rat basophilic leukemia (RBL-2H3) cells with an IC50 of $20.9 \mathrm{lg} / \mathrm{ml}$. In addition, SPRE exhibited only moderate cytotoxicity on human keratinocyte cells, with CC50 of 33.6 $\mathrm{lg} / \mathrm{ml}$. These findings support the potential use of SPRE as a nutraceutical for antibacterial, anti-inflammatory and antiallergic proposes.

The historical method for identification of new isolated microbes is dependent on the comparison of an accurate morphologic and phenotypic description of type strains or typical strains with the accurate morphologic and phenotypic description of the isolate to be identified. Microbiologists authoring standard references such as Bergey's Manual of Systematic Bacteriology or the Manual of Clinical Microbiology or compiling results from well-characterized strains such as those found at the Centers for Disease Control and Prevention or the American Type Culture Collection (ATCC) would publish tables summarizing the characteristics of each species of bacteria (Murray et al. 1999). Microbiologists would try to match the results for their unknown bacterial strain with a group in these tables. Not infrequently, there would be no perfect match and a judgment would have to be made about the most probable identification. Although various schema and computer programs were devised to help in these judgments, identification could vary among laboratories (Sussman et al. 1986). In the 1980s, a new standard for identifying bacteria began to be developed. In the laboratories of Woese and others, it was shown that phylogenetic relationships of bacteria, and, indeed, all life-forms, could be determined by comparing a stable part of the genetic code (Woese 1985).

Candidates for this genetic area in bacteria included the genes that code for the $5 \mathrm{~S}$, the $16 \mathrm{~S}$ (also called the small subunit), and the 23S rRNA and the spaces between these genes. The part of the DNA now most commonly used for taxonomic purposes for bacteria is the 16S-rRNA gene (Garrity et al. 2001, Tortoli, 2003). The 16S- rRNA gene is also designated 16S-rDNA, and the terms have been used interchangeably: current ASM policy is that "16S-rRNA gene" be used. The 16S- rRNA gene can be compared not only among all bacteria but also with the 16S-rRNA gene of archeobacteria and the $18 \mathrm{~S}$ rRNA gene of eucaryotes.

The use of PCR, over the last years, rapid purification, and automated DNA sequencing has significantly reduced the time to yield a high-quality sequence. The use of 16S-rRNA gene sequencing to study the relatedness of prokaryotic species is well 
established and has led to increased availability of $16 \mathrm{~S}-$ rRNA databases. The convergence of these technical and computational advances has also enhanced the application of $16 \mathrm{~S}$ - rRNA gene sequence analysis to bacterial identification (Rantakokko-Jalava et al., 2000). Recently, it was reported that subtle sequence differences in the $16 \mathrm{~S}$ rRNA gene could be used for bacteria identification (Sacchi et al., 2002) and for subtyping and identifying bacterial clones (Nilsson et al., 2003). Molecular techniques are used as identification tools for specific strains, genotyping and confirmation of the results. PCR and sequence analysis provide further information on the phylogenetic characteristics of the strains identified Harwood et al. (2009). Direct PCR (DPCR) provides an improved method for the detection and quantification of bacteria in samples (Fode-Vaughan et al. 2001). This is a more rapid and simple approach because the untreated environmental sample is used directly as a template in PCR, eliminating the steps of cell recovery or DNA extraction.

The information about prevalence and types of bacteria and Actinomycetes of pomegranate roots in Taif is scarce. To our knowledge, no research has been conducted on prevalence, isolation and identification of bacteria and potential bacterial pathogens and its distribution in pomegranate plant as well as their antibiotic susceptibility pattern. Therefore, the objective of this study was to isolate and identify potential bacterial isolates using morphological, biochemical, physiological, API test and 16S-rRNA techniques. In addition to, its distribution in pomegranate root area and their antibiotic susceptibility pattern. Also, we report the antimicrobial activity of pomegranate fruit extracts against different types of isolated bacteria from roots and soil surrounding the plant roots.

\section{Materials and Methods}

\section{Sampling}

Soil samples and pomegranate roots were collected from Al Shafa area and the university campus in Taif. Specimens of roots and soil were periodically collected. Standard microbiological techniques were used in isolation and identification of microorganisms (Holt et al., 1994).

\section{Media}

Different media were used for enumeration, isolation and identification.e.g. Plate count (Diffico, 1990), MacConky agar media, nutrient agar (Diffico, 1990), Jensen's media (Jensen et al. 2005), modified Tarozzi agar (Linzenmeier, 1958)and S. griseus agar media (Shirato and Motoyama, 1966).Nfree media for $\mathrm{N}_{2}$ - fixing bacteria, Sabarroid media for fungi and MacConky media for pathogens.

\section{Enumeration of Microorganism}

Samples were collected from Taif regions. Samples were enumerated within $24 \mathrm{~h}$ by making tenfold serial dilution of samples using physiological saline. From the diluted sample, using a dropper pipette, $1 \mathrm{ml}$ of each dilution was dropped onto Petri dish then the plate count agar for bacteria, and Jensen's agar medium, Tarozzi agar, $S$. griseus medium for Actinomycetes and Streptomyces were poured (Gerdhardt et al. 1984). Triplicates of plates were used for each dilution. Aliquots of freshly sieved soil were accurately weighed and then dried at $105^{\circ} \mathrm{C}$ for 3 days. The samples soil or grinded roots were then reweighed after they were first allowed to cool to room temperature in a desiccator. The factor for conversion of fresh weight to dry weight of soil were calculated, and all results were expressed 
per gram (dry weight) of soil, rhizosphere soil and/or dry gram roots.

\section{Isolation of Microorganisms}

Different selective media were used as mentioned above in order to isolate potent Actinomycetes and/or Streptomyces for antibiotic production and different types of bacteria from the collected samples. Characterization of isolated microorganisms based on the morphological, physiological, and the biochemical characteristics presented in Bergey's Manual of Systematic Bacteriology (Holt et al. 1994). Samples were processed within $24 \mathrm{~h}$ by making tenfold serial dilution of samples using physiological saline. From the diluted sample, using a dropper pipette, $1 \mathrm{ml}$ of each dilution was dropped onto Petri dish then the nitrogen- free media for $\mathrm{N}_{2}$ - fixing bacteria, MacConky media for pathogens and Jensen media, nitrate-sucrose agar, for Actinomycetes were poured (Gerdhardt et al. 1984). Duplicates of plates were used for each dilution. Plates were incubated for $24-$ $48 \mathrm{~h}$ at $30^{\circ} \mathrm{C}$ for bacteria and $10-15$ for Actinomycetes in an incubator. Each inoculum of microorganism developed into a discreet colony. All plates yielding 30 300 colonies were counted. The number of viable microorganisms in the sample were calculated from the number of colonies formed, the volume of inoculum used by dropper pipette and the dilution factor expressed in colony forming unit (CFU) (Krieg, 1984).

\section{Identification and Characterization of Microorganism}

The morphological characteristics of the isolates were identified by gram stain and biochemical reactions. The biochemical reactions include glucose fermentation, oxidase test, catalase production reaction; cell motility and reaction in tryptose soya broth were performed. According to Bergey's Manual of Determinative Bacteriology (Holt et al., 1994) and the APi Kit profiling (Api, bioMerieux, France, 2009) isolates were identified and named based on morphological, physiological and biochemical characteristics. The genusspecific $16 \mathrm{~S}$ - rRNA gene analysis were used to identify the isolates at the molecular level for further confirmation.

\section{Culture Condition and Growth}

Inocula were pregrown in $10 \mathrm{ml} \mathrm{LB}$ broth medium for $12 \mathrm{~h}$. Cells were grown aerobically in $50 \mathrm{ml}$ Erlenmeyer flasks. Flasks were filled to no more than $20 \%$ capacity. All isolates were growing at $30^{\circ} \mathrm{C}$ in an incubator shaker at $150 \mathrm{rpm}$. The absorbency of the culture was measured with a spectrophotometer at $660 \mathrm{~nm}$. Cultures were usually harvested at absorbency 0.660 . Cells were harvested by centrifugation for $5 \mathrm{~min}$ at 3,000 $\mathrm{x}$ g at room temperature (Krieg, 1984).

\section{Antimicrobial Susceptibility}

All isolates belonging to various genera were tested. Antimicrobial susceptibility testing was performed using the disc diffusion method on Mueller-Hinton agar plates for all bacteria and pathogens. The plates were incubated aerobically at $30^{\circ} \mathrm{C}$ for 18-24 hours for bacteria. The diameters of the zones of inhibition were measured with a ruler and compared with a zoneinterpretation chart (NCCLS, 1999). Escherichia coli were used as the control. The antibiotics tested on each disc were Ampicillin $25 \mu \mathrm{g}$, Nalidixic Acid $30 \mu \mathrm{g}$, Ceftriaxone $30 \mu \mathrm{g}$, Augmentin $(20 / 10 \mu \mathrm{g})$, Tetracycline (62.2\%), Piperacillin $100 \mu \mathrm{g}$, Ciprofloxacin $30 \mu \mathrm{g}$, Gentamicin $10 \mu \mathrm{g}$ and Amikacin $30 \mu \mathrm{g}$. Results of disk diffusion 
method were interpreted in accordance to the Clinical and Laboratory Standards Institute (CLSI, 2009). Streptomyces and Actinomycetes were tested for production of antibiotics (data not shown).

\section{Disc Diffusion Method}

Antibacterial activities of the crude extracts were tested by using agar disc diffusion method as described by Kirby-Bauer with modification (Bauer et al. 1966).

\section{S-rRNAgeneAnalysis}

Standard DNA methods (DNA isolation (using GenElute Bacterial Genomic DNA Kit, Mini-(SIGMA), agarose gel electrophoresis of DNA, restriction enzyme digestion, will be used as described by Ausubel et al. (1989) and Maniatis et al. (1982). To identify the isolates at the molecular level, the genus specific $16 \mathrm{~S}$ rRNA gene analysis using PCR were carried out. The forward primers and reverse primer were designed according to the convention of the Oligonucleotide Probe Database (OPD). The PCR were performed in a $50 \mu 1$ reaction volume containing $1 \mathrm{X}$ PCR buffer (10mM Tris- $\mathrm{HCl} \mathrm{pH} 8.3,50 \mathrm{mM} \mathrm{KCl}, 2 \mathrm{mM}$ $\mathrm{MgCl}_{2}, 0.01 \%$ (w/v) gelatine), $250 \mu \mathrm{M}$ each of dGTP, dATP, dCTP and dTTP (dNTPs), 2.5 units of Taq DNA polymerases, 100 pmol of each primer and the DNA template, which released from the bacterial cells by boiling in a water bath for 5 min to lyses the cells and then the tubes were spun briefly to collect the condensate (Ausubel et al., 1989). PCR reaction conditions were: $94^{\circ} \mathrm{C}$ for $3 \mathrm{~min}$; 35 cycles of denaturation at $94^{\circ} \mathrm{C}$; annealing at $52^{\circ} \mathrm{C}$; and extension at $72^{\circ} \mathrm{C}$ for $2 \mathrm{~min}$ each, followed by $7 \mathrm{~min}$ extension at $72^{\circ} \mathrm{C}$. Sequencing of the $1000 \mathrm{bp}$ PCR product were carried out with the automated DNA sequencer (ABI, Gene line DNA sequencing, New York). The deduced sequence was aligned with the DNA data base available at the gene bank using the BLAST of the (http\# www.ncbi.nlm.nih.gov/Blast/cgi).

\section{Sequence Similarities and Phylogenetic Analysis}

The BLAST program (www.ncbi.nlm.nih.gov/blst) were employed in order to assess the degree of DNA similarity. Multiple sequence alignment and molecular phylogeny were evaluated using BioEdit software (Hall, 1999).

\section{Pomegranate Fruits}

The pomegranate fruits were collected from a taify farm at Taif. Different parts of the fruits was used rind, juice, seeds (white and red) and whole fruit extracted with methanol and aqueous extract.

\section{Methods of Extraction}

The fresh fruits was cleaned, freeze-dried and grounded into fine powder using an electric blender. The powder was dried in an oven at $40^{\circ} \mathrm{C}$ for $24 \mathrm{~h}$, then the fine powder was sieved through 24-mesh. The fine powdered sample $(10 \mathrm{~g})$ was extracted with $250 \mathrm{ml} 80 \%$ methanol in water at room temperature $\left(25^{\circ} \mathrm{C}\right)$ for $24 \mathrm{~h}$ in a shaking water bath. The extract was filtered by a Millipore filter with a $0.45 \mu \mathrm{m}$ nylon membrane under vacuum at $25^{\circ} \mathrm{C}$. The samples wasstored at $4^{\circ} \mathrm{C}$ until use. For aqueous extract the fine powdered sample $(10 \mathrm{~g})$ was extracted with $100 \mathrm{ml}$ of distilled water.

\section{Data Analysis}

All determinations were carried out in triplicates and the statistical analyses were carried out using SPSS 13.0. 


\section{Results and Discussion}

\section{Prevalence of Microorganisms in Pomegranate Roots}

Total bacterial count and actinomycetes were estimated in soil, rhizosphere soil, as well as roots of pomegranate (Table 1). Actinomycetes and Streptomyces enumerated on 3 different media shown in Table (1). Moisture contents were ranged from 78.8$86.2 \%$ in all collected samples. The total bacterial count in soil, rhizosphere soil and roots of pomegranate was $1.7 \times 10^{5}$ $23.6 \times 10^{5}, 2.3 \times 10^{6}-13.0 \times 10^{6}$, and $1.7 \times 10^{3}$ $28.3 \times 10^{3}$, respectively. The total bacterial count was higher in rhizosphere soil than free soil as well as inside roots of pomegranate. This could be explained by abundance of plant root exudates, nutrients attracted by plant roots from surrounding soil and microorganisms exudates. The R/S ratio was between $2.3-5.51$ in all analyzed samples. The presence and numbers of Actinomycetes and Streptomyces were various among samples of soil, rhizosphere soil and/or plant roots (Table 1). In general, numbers were higher in rhizosphere soil than free soil or inside plant roots. No growth was observed on S. griseus medium or Tarozzimedium for one free soil sample (2) or inside root sample (3).

Some microorganisms are able to colonize soil surrounding plant roots, the rhizosphere, making them come under the influence of plant roots (Hiltner 1904, Kennedy 2005). Rhizobacteria are rhizosphere competent bacteria able to multiply and colonize plant roots at all stages of plant growth, in the presence of a competing microflora (Antoun and Kloepper 2001) where they are in contact with other microorganisms. This could be explained by the interactions between plants and microorganisms and can be classified as pathogenic, saprophytic, and beneficial (Lynch1990). Beneficial interactions involve plant growth promoting rhizobacteria (PGPR), this refers to a group of soil and rhizosphere free-living bacteria colonizing roots in a competitive environment and exerting a beneficial effect on plant growth (Kloepper 2003, Bakker et al. 2007). However, numerous researchers considered rhizobacteria as endophytic bacteria in symbiotic association with plants (Bakker et al. 2007) e.g. Rhizobia with legumes and the actinomycetes with Frankia. Kloepper 2003 and Bakker et al. (2007) reported that among PGPRs are representatives of the following genera: Acinetobacter, Agrobacterium, Arthrobacter, Azoarcus, Azospirillum, Azotobacter, Bacillus, Burkholderia, Enterobacter, Klebsiella, Pseudomonas, Rhizobium, Serratia, Azospirlliumand Thiobacillus. Some of these genera such as Azoarcus spp., Herbaspirillum, and Burkholderia include endophytic species. However, Pseudomonas and Bacillus species constitute, together with Streptomyces species, the most bacteria often found in the rhizosphere of many plants. The soil microflora largely depends on the type of soil, temperature, moisture, plant growth, nutrients, $\mathrm{pH}$, and many other factors which may vary between locations but also within a single plot and over very small distances (OECD, 2007).

\section{Morphological, and Biochemical Characterization of Isolate}

Isolates from free soil, rhizosphere soil and/or roots of pomegranate were isolated by enrichment culture technique and deposited in our microbial bank at Taif University, Saudi Arabia in our laboratory. The isolates were identified on the basis of their cultural, physiological and biochemical characteristics according to Bergey's Manual of Determinative Bacteriology ( $9^{\text {th }}$ edition) 
(Holt et al. 1994) and Api kit profiles (ApiBioMerieuxsa, 2009). About 102 isolates were collected in pure culture, 58 isolates were bacteria and 44 were Actinomycetes and Streptomyces. Phenotypic examination of the recovered isolates revealed that they belong to the genera of Bacillus, Sacchromyces, Azotobacter, Azospirllum, Enterobacter, Herbaspirllum, Staphlococcus, Acintobacter, Streptococcus, Klebseilla, Streptomyces Actinomycesand Pseudomonas (Table 2). About 37.3, 53.9 and $8.8 \%$ of isolated strains were isolated from free soil, rhizosphere and inside roots, respectively. All selected strains showed optimal growth at $30^{\circ} \mathrm{C}$ but grows in different media. Strains were local isolates isolated by enrichment culture technique and deposited in our microbial bank at Taif University, Saudi Arabia in our laboratory.

\section{S rRNA Gene and Genetic Identification of Isolates}

Sequencing of $16 \mathrm{~S}-\mathrm{rRNA}$ gene as a PCR based technique was used to identify the selected bacterial isolates. According to the alignment at the National Center for Biotechnology Information (NCBI), the sequences of studied isolates in (Table 2) were identified as Bacillus subtilis, Sacchromyces cerevieace, Azospirllum lipeforum, Azotobacterchroococcum, Herbaspirllum seropedicae, Entrobacter aerogenes, S. pneumoniae, Acinetobacter calcoaceticus, S. pyogenes, K. pneumonia, Streptomyces griseus, Actinomyces octodloyts, P. aerogenosa (DeSantis et al, 2006, El- Tarras et al. 2012, Shahaby et al. 2012, Shahaby 2014, Shahaby et al. 2015).

\section{Antibiotic Resistance Profile of Bacterial Isolate}

This study showed that antimicrobial susceptibility of isolated bacteria was:
Ampicillin (37.7\%), Nalidixic Acid (62.3\%), Ceftriaxone (73.6\%), Augmentin (64.2\%), Tetracycline $(75.5 \%)$, Gentamycin $(75.5 \%)$, Ciprofloxacin (66.04\%), Piperacillin (26.4\%), and Amikacin (54.7\%), (Table 3). Microorganisms are normally present in soil and more around plant roots. Some bacteria are pathogens and can live and survive inside roots of plants. The use of antibiotics for treatment of severe infections in human is routine in clinics and hospitals practice resulting in increased drug resistance. In this study, among the commonly used topical antibiotics 73.6 and $62.3 \%$ of all strains were piperacillin and ampicillin resistant, respectivily. $S$. pyogones isolate was sensitive to all antibiotics except for ciprofloxacin and piperacillin. While all $S$. pneumonia isolates were sensitive tonalidixic acid and ceftriaxone (Cef). About $73.6 \%$ and $69.3 \%$ of all strains were resistant to both piperacillin and ampicillin, respectively. Moreover, $60.0 \%$ of all strains of $E$. aerogenes were nalidixic acid and piperacillin resistant. All $P$. aerogenosa isolates were resistant to ampicillin, augmentin and amikacin antibiotics. In addition to, $75.0 \%$ of $K$. pneumonia isolates were resistant to ampicilin, augmentin and amikacin. The $\mathrm{N}_{2}$ - fixing $A$. chroococcum isolates were susceptible to tetracycline, while $71.4 \%$ of isolates were resistant to ceftriaxone and ciprofloxacin. The resistance of $A$. lipeforum isolates was between 10-80\% for all antibiotics. While Herbaspirllum spp.resistance to antibiotics was 11.1-66.7\%. Acinetobacter baumannii isolates were susceptible to both nalidixic acid and augmentin however, $50 \%$ of isolates were resistant to other antibiotics tested.

These results are in agreement with the study conducted by Caldwell et al. (1992), Joseph, (2009), Anagaw et al. (2011), Shahaby et al. (2015) and Tewelde et al. (2013). The increased susceptibility of some 
isolates e. g. S. pneumonia, $S$. pyogones, $K$. pneumonia, $P$. aerogenosa and $A$. baumanni might be due to root exudates of pomegranate plant. Also, the reason for increased resistance for some antibiotics may be earlier exposure of the isolates to these drugs. In addition to, these drugs are very common due to low cost and often purchased without prescription in different areas (Jorgensen et al. 2015).

Table.1 Total Bacterial Count,Actinomycetesand Streptomyceson Various Media in Soil, Rhizosphereand Roots of Pomegranateplant

\begin{tabular}{|l|c|c|c|l|l|l|}
\hline \multirow{2}{*}{ Sample $^{+}$} & \multicolumn{7}{|c|}{ Total count } \\
\cline { 2 - 7 } & Bacteria Actimycetes & \multicolumn{5}{|c|}{} \\
\cline { 2 - 7 } & Moisture \% & & R/S ratio & $\begin{array}{l}\text { Jensen's } \\
\text { Medium }\end{array}$ & $\begin{array}{l}\text { S. griseus } \\
\text { Medium }\end{array}$ & $\begin{array}{l}\text { Tarozzi } \\
\text { Medium }\end{array}$ \\
\hline Soil & 78.8 & $23.6 \times 10^{5}$ & 5.51 & $1.6 \times 10^{4}$ & $0.8 \times 10^{4}$ & $2.0 \times 10^{4}$ \\
\hline Rhizosphere & 78.8 & $13.0 \times 10^{6}$ & & $0.3 \times 10^{5}$ & $1.1 \times 10^{4}$ & $0.1 \times 10^{5}$ \\
\hline Root & & $28.3 \times 10^{3}$ & & $1.6 \times 10^{3}$ & $0.28 \times 10^{5}$ & $2.83 \times 10^{3}$ \\
\hline Soil & 86.2 & $9.31 \times 10^{5}$ & 2.5 & $12.93 \times 10^{3}$ & - & $11.38 \times 10^{3}$ \\
\hline Rhizosphere & 86.2 & $2.3 \times 10^{6}$ & & $11.1 \times 10^{2}$ & $9.3 \times 10^{4}$ & $3.1 \times 10^{3}$ \\
\hline Root & & $1.7 \times 10^{3}$ & & $25.1 \times 10^{4}$ & $12.1 \times 10^{3}$ & $18.1 \times 10^{2}$ \\
\hline Soil & 82.5 & $1.7 \times 10^{5}$ & 2.3 & $5.3 \times 10^{3}$ & $1.6 \times 10^{4}$ & $1.1 \times 10^{2}$ \\
\hline Rhizosphere & 82.5 & $3.9 \times 10^{6}$ & & $0.5 \times 10^{4}$ & $0.3 \times 10^{2}$ & $3.1 \times 10$ \\
\hline Root & & $2.8 \times 10^{6}$ & & $1.4 \times 10^{4}$ & - & - \\
\hline \\
+, Each sample is an average of 5 mixed samples \\
-, No growth; *, Jensen eta.l (2005); **, Shirato and Motoyama (1966); ***, Linzenmeier $(1958)$
\end{tabular}

Table.2 Prevalence of Bacterial Isolates in Free Soil, Rhizosphere and Roots of Pomegranate

\begin{tabular}{|l|c|c|c|c|}
\hline \multicolumn{1}{|c|}{ Isolates } & Soil & Rhizosphere & Roots & Total \\
\hline Bacillus subtilis & 2 & 4 & 1 & 7 \\
\hline Sacchromycescerevieace & 2 & 3 & - & 5 \\
\hline Azospirllumlipeforum & 3 & 5 & 2 & 10 \\
\hline Azotobacterchroococcum & 3 & 4 & - & 7 \\
\hline Entrobacteraerogenes & 1 & 3 & 1 & 5 \\
\hline Streptococcus spp. & - & 1 & - & 1 \\
\hline Herbaspirllumspp & 3 & 4 & 2 & 9 \\
\hline Actinomycesspp & 10 & 12 & 1 & 23 \\
\hline Streptomyces spp & 11 & 10 & - & 21 \\
\hline K. pneumoniae & 1 & 2 & 1 & 4 \\
\hline Acinetobacterspp. & - & 2 & - & 2 \\
\hline S. pneumoniae & 1 & 2 & - & 3 \\
\hline P. aerogenosa & 1 & 3 & 1 & 5 \\
\hline & 38 & 55 & 9 & 102 \\
\hline
\end{tabular}


Table.3 Selected Antibiotics Sensitivity Pattern of Selected Isolated Microorganisms

\begin{tabular}{|c|c|c|c|c|c|c|c|c|c|c|}
\hline \multirow{2}{*}{$\begin{array}{c}\text { Antibiotic* } \\
\text { Isolates }\end{array}$} & \multicolumn{10}{|c|}{ Number of strains sensitive to antibiotics (\%) } \\
\hline & No & Amp & Nal & Cef & Aug & Tet & Gen & Cip & Pip & Ami \\
\hline \multicolumn{11}{|l|}{$\mathrm{G}^{+}$bacteria } \\
\hline B. subtilis & 7 & $\begin{array}{l}4 \\
57.1 * *\end{array}$ & $\begin{array}{l}5 \\
71.4 \\
\end{array}$ & $\begin{array}{l}6 \\
85.7 \\
\end{array}$ & $\begin{array}{l}4 \\
57.1 \\
\end{array}$ & $\begin{array}{l}4 \\
57.1 \\
\end{array}$ & $\begin{array}{l}4 \\
57.1 \\
\end{array}$ & $\begin{array}{l}65.7 \\
85.7\end{array}$ & $\begin{array}{l}3 \\
42.9 \\
\end{array}$ & $\begin{array}{l}5 \\
71.4 \\
\end{array}$ \\
\hline A. chroococcm & 7 & $\begin{array}{l}3 \\
42.9 \\
\end{array}$ & $\begin{array}{l}65.7 \\
85.7\end{array}$ & $\begin{array}{l}2 \\
28.6 \\
\end{array}$ & $\begin{array}{l}5 \\
71.4\end{array}$ & $\begin{array}{l}7 \\
100\end{array}$ & $\begin{array}{l}5 \\
71.4 \\
\end{array}$ & $\begin{array}{l}2 \\
28.6\end{array}$ & nd & $\begin{array}{l}4 \\
57.1\end{array}$ \\
\hline S. pneumoniae & 3 & $\begin{array}{l}2 \\
66.7 \\
\end{array}$ & $\begin{array}{l}3 \\
100 \\
\end{array}$ & $\begin{array}{l}3 \\
100 \\
\end{array}$ & $\begin{array}{l}2 \\
66.7 \\
\end{array}$ & $\begin{array}{l}2 \\
66.7 \\
\end{array}$ & $\begin{array}{l}1 \\
33.3 \\
\end{array}$ & $\begin{array}{l}2 \\
66.7 \\
\end{array}$ & $\begin{array}{l}1 \\
33.3 \\
\end{array}$ & $\begin{array}{l}2 \\
66.7 \\
\end{array}$ \\
\hline S. pyogones & $\begin{array}{l}1 \\
100\end{array}$ & $\begin{array}{l}1 \\
100 \\
\end{array}$ & $\begin{array}{l}1 \\
100 \\
\end{array}$ & $\begin{array}{l}1 \\
100 \\
\end{array}$ & $\begin{array}{l}1 \\
100 \\
\end{array}$ & $\begin{array}{l}1 \\
100 \\
\end{array}$ & $\begin{array}{l}1 \\
100 \\
\end{array}$ & 0 & 0 & $\begin{array}{l}1 \\
100 \\
\end{array}$ \\
\hline Total $\mathrm{G}^{+}$ & 18 & $\begin{array}{l}10 \\
55.6 \\
\end{array}$ & $\begin{array}{l}15 \\
83.3 \\
\end{array}$ & $\begin{array}{l}12 \\
66.7 \\
\end{array}$ & $\begin{array}{l}12 \\
66.7 \\
\end{array}$ & $\begin{array}{l}14 \\
77.8 \\
\end{array}$ & $\begin{array}{l}11 \\
61.1 \\
\end{array}$ & $\begin{array}{l}10 \\
55.5 \\
\end{array}$ & $\begin{array}{l}4 \\
22.2 \\
\end{array}$ & $\begin{array}{l}12 \\
66.7 \\
\end{array}$ \\
\hline \multicolumn{11}{|l|}{ Gbacteria } \\
\hline A. lipeforum & 10 & $\begin{array}{l}2 \\
20.0 \\
\end{array}$ & $\begin{array}{l}5 \\
50.0 \\
\end{array}$ & $\begin{array}{l}9 \\
90.0 \\
\end{array}$ & $\begin{array}{l}8 \\
80.0 \\
\end{array}$ & $\begin{array}{l}8 \\
80.0 \\
\end{array}$ & $\begin{array}{l}9 \\
90.0 \\
\end{array}$ & $\begin{array}{l}9 \\
90.0 \\
\end{array}$ & nd & $\begin{array}{l}6 \\
60.0 \\
\end{array}$ \\
\hline E. aerogenes & 5 & $\begin{array}{l}3 \\
60.0 \\
\end{array}$ & $\begin{array}{l}2 \\
40.0 \\
\end{array}$ & $\begin{array}{l}4 \\
80.0 \\
\end{array}$ & $\begin{array}{l}4 \\
80.0 \\
\end{array}$ & $\begin{array}{l}4 \\
80.0\end{array}$ & $\begin{array}{l}4 \\
80.0\end{array}$ & nd & $\begin{array}{l}2 \\
40.0 \\
\end{array}$ & $\begin{array}{l}3 \\
60.0\end{array}$ \\
\hline H. seropedicae & 9 & $\begin{array}{l}3 \\
33.3 \\
\end{array}$ & $\begin{array}{l}4 \\
44.4 \\
\end{array}$ & $\begin{array}{l}8 \\
88.9 \\
\end{array}$ & $\begin{array}{l}7 \\
77.8 \\
\end{array}$ & $\begin{array}{l}6 \\
66.7 \\
\end{array}$ & $\begin{array}{l}5 \\
55.6 \\
\end{array}$ & $\begin{array}{l}7 \\
77.8 \\
\end{array}$ & $\begin{array}{l}5 \\
55.6 \\
\end{array}$ & $\begin{array}{l}6 \\
66.7 \\
\end{array}$ \\
\hline K. pneumoniae & 4 & $\begin{array}{l}1 \\
25.0 \\
\end{array}$ & $\begin{array}{l}3 \\
75.0 \\
\end{array}$ & $\begin{array}{l}4 \\
100 \\
\end{array}$ & $\begin{array}{l}1 \\
25.0 \\
\end{array}$ & $\begin{array}{l}4 \\
100 \\
\end{array}$ & $\begin{array}{l}3 \\
75.0 \\
\end{array}$ & $\begin{array}{l}4 \\
100 \\
\end{array}$ & $\begin{array}{l}3 \\
75.0 \\
\end{array}$ & $\begin{array}{l}1 \\
25.0 \\
\end{array}$ \\
\hline P. aerogenosa & 5 & 0 & $\begin{array}{l}2 \\
40.0 \\
\end{array}$ & $\begin{array}{l}1 \\
20.0 \\
\end{array}$ & 0 & $\begin{array}{l}3 \\
60.0 \\
\end{array}$ & $\begin{array}{l}5 \\
100 \\
\end{array}$ & $\begin{array}{l}5 \\
100 \\
\end{array}$ & nd & 0 \\
\hline A. baumannii & 2 & $\begin{array}{l}1 \\
50.0 \\
\end{array}$ & $\begin{array}{l}2 \\
100 \\
\end{array}$ & $\begin{array}{l}1 \\
50.0 \\
\end{array}$ & $\begin{array}{l}2 \\
100 \\
\end{array}$ & $\begin{array}{l}1 \\
50.0 \\
\end{array}$ & $\begin{array}{l}1 \\
50.0 \\
\end{array}$ & nd & nd & $\begin{array}{l}1 \\
50 \\
\end{array}$ \\
\hline Total $\mathrm{G}^{-}$ & 35 & $\begin{array}{l}10 \\
28.6 \\
\end{array}$ & $\begin{array}{l}18 \\
51.4 \\
\end{array}$ & $\begin{array}{l}27 \\
77.1 \\
\end{array}$ & $\begin{array}{l}22 \\
62.9 \\
\end{array}$ & $\begin{array}{l}26 \\
74.3 \\
\end{array}$ & $\begin{array}{l}27 \\
77.1 \\
\end{array}$ & $\begin{array}{l}25 \\
71.4 \\
\end{array}$ & $\begin{array}{l}10 \\
28.6 \\
\end{array}$ & $\begin{array}{l}17 \\
48.6 \\
\end{array}$ \\
\hline Overall total & 53 & $\begin{array}{l}20 \\
37.7 \\
\end{array}$ & $\begin{array}{l}33 \\
62.3 \\
\end{array}$ & $\begin{array}{l}39 \\
73.6 \\
\end{array}$ & $\begin{array}{l}34 \\
64.2 \\
\end{array}$ & $\begin{array}{l}40 \\
75.5 \\
\end{array}$ & $\begin{array}{l}38 \\
71.7 \\
\end{array}$ & $\begin{array}{l}35 \\
66.04 \\
\end{array}$ & $\begin{array}{l}14 \\
26.4\end{array}$ & $\begin{array}{l}29 \\
54.7 \\
\end{array}$ \\
\hline
\end{tabular}

*Ampicillin (Amp), Nalidixic Acid (Nal), Ceftriaxone (Cef), Augmentin (Aug), Tetracycline (Tet), Gentamycin (Gen), Ciprofloxacin (Cip), Piperacillin (Pip), Amikacin (Ami), Not done (nd).**, \% sensitive strains

Table.4 Effect of Different Pomegranate Extracts on the Selected Isolated Bacterial Cultures in Solid Medium

\begin{tabular}{|l|l|l|l|}
\hline \multicolumn{5}{|c|}{ Diameter of inhibitionzoneinmm(DIZ) } \\
\hline Bacteria Tested & Rind & Seeds Extract (Juice) & Whole fruit \\
\hline B. subtilis & 20 & 18 & 11 \\
\hline Entrobacteraerogenes & 19 & 16 & 18 \\
\hline K. pneumonia & 21 & 24 & 26 \\
\hline S. pneumoniae A. chroococcum & 20 & 17 & 19 \\
\hline & 18 & 19 & 12 \\
\hline A. lipoferum & 21 & 20 & 18 \\
\hline P. aerogenosa & 17 & 22 & 15 \\
\hline Herbaspirllumseropedicae & 18 & 19 & 20 \\
\hline
\end{tabular}




\section{Effect of Pomegranate Fruit Extracts}

Phytochemical constituents of medicinal plants are secondary metabolites that may act as antimicrobial agents (Marjorie 1999). In this study extracts of pomegranate fruits were evaluated for their antimicrobial activities. Crude alcoholic extracts of rind, seeds extract (juice) and whole fruit were evaluated against isolated Gram-positive and Gram-negative by agar disc diffusion method. As shown in Table 4, while, fruit parts were active against all tested isolated bacteria (B. subtilis, E. aerogenes, $K$. pneumonia and $P$. aerogenosa), and moreover, against $\mathrm{N}_{2}$-Fixing bacteria (A. chroococcum, A.lipoferum and $H$. seropedicae). Rind extract was less active against $P$. aerogenosa $(17 \mathrm{~mm})$, juice against E. aerogenes $(16 \mathrm{~mm})$, whole fruit extract against $B$. subtilis $(11 \mathrm{~mm})$. The inhibition zone diameters of alcoholic extracts of different parts of pomegranate fruit against the eight tested bacteria ranged between 11 and $26 \mathrm{~mm}$ (Table 4). In general, juice (seed extract) alcoholic extract was relatively more active than extracts of other parts of the fruit. The descending order of activity of the extracted parts of the plant fruit was jucie, rind and whole fruit, respectively (Table 4). On the other hand, Gram- positive bacteria, B. subtilis S. pneumoniae and A. chroococcum were more sensitive than Gram-negative and their inhibition zones ranged between 11 and $19 \mathrm{~mm}$. The higher susceptibility of the tested Gram-positive bacteria than Gram-negative bacteria to pomegranate fruit extracts is consistent with previous studies on the antibacterial activity of natural products (Smith-Palmer et al. 1998, Ceylan, Fung 2004, Lopez et al. 2005, Panichayupakaranant et al. 2010, Howell1 and D'Souza, 2013). This may explained by fact that Gram-negative bacteria possess an outer membrane which acts as a barrier which prevents or decreases the penetration of numerous antimicrobials (Nikaido1996, Gao et al 1999, Duffy and Power 2001). Because Gram-positive bacteria lack the outer membrane, and possess only a cytoplasmic membrane, it is more vulnerable to damaging molecules and this leads to the leakage of their cytoplasm contents(KalembaandKunicka2003).

$P$. aeruginosa and E. aerogenes were found to be more sensitive to different extracts of pomegranate fruit compared to the other tested Gram-negative bacteria. This is rather interesting because both organisms are known to be less susceptible to antimicrobials including antibiotics, preservatives, antiseptics and disinfectants (Russell 1991, McDonnell and Russell 1999). This resistance is attributed to the less permeable outer membrane of $P$. aeruginosa (McDonnell and Russell 1999).K. pneumonia was the least sensitive Gram-negative bacterium. It was reported previously that this bacterium have a lower susceptibility to the antibacterial effect of Nigella sativa extracts (Burkill 1985). This lower sensitivity may be attributed to the surrounding capsule which is made of acidic polysaccharides (Domenico et al. 1994). The large partially negatively charged macromolecular structure of the capsule was reported to decrease the uptake of antimicrobials like peptides (Campos et al. 2004). This study showed that the capsule might also decrease the uptake of the antibacterial phytoconstituents of $C$. erectus extracts presumably, as a result of their repulsion or attraction to its charged polysaccharide.

In conclusion, Extracts of different parts of pomegranate fruit investigated in this study possessed broad-spectrum antimicrobial activity against Gram-positive, and Gramnegative. The broad-spectrum antibacterial activity of the fruit extracts, confirms its use 
as a health remedy in folklore medicine. Therefore, it may be concluded that fruits of pomegranate extracts have broad spectrum antimicrobial activity and their activity could be attributed, to a great extent, to their contents of alkaloids and flavonoids.

\section{Acknowledgment}

We thank and appreciate the staff of Biotechnology and Genetic Engineering Unit (BGEU) for their help in conducting the experimental part of the study and Taif University for providing the required researchfacilities. This research project was supported financially under contract No.1/ $435 / 3575$ by the Department of Higher Studies and Scientific Research, Taif University, Taif, Saudi Arabia.

\section{References}

Anagaw B, Fantahun B, Berhanu A, Yeshambel B, Andargachew $\mathrm{M}$. 2011. Bacteriology of ocular infections and their antibiotic susceptibility pattern in Gondar University Hospital, North West, Ethiopia. Ethiop Med. J. 49(2):11723.

Antoun H, Kloepper JW. 2001. Plant growth-promoting rhizobacteria (PGPR). In: Brenner S, Miller JH (eds) Encyclopedia of genetics. Academic, New York, pp 1477-1480.

Api. BioMerieux. 2009. BioMerieux sa 69280 MarcyI'Etoile, France. http://www. biomerieux.com.

Arseculeratne SN, AALGunatilaka, RGPanabokke. 1985. Studies on medicinal plants of Sri Lanka. Part 14.9:13: 323-335.

Ausubel FM, RBrent, REKingston, DDMoore, JG Seidman, JASmith, K. Struhl. 1989. Current protocols in molecular biology. John Wily \&
Sons, Inc., New York.

Bakker PAHM, Raaijmakers JM, Bloemberg GV, Hofte M, Lemanceau P, Cooke M.2007. New perspectives and approaches in plant growthpromoting rhizobacteria research. Eur J Plant Pathol 119:241-242.

Bauer AW, WMMKirby, JCSherris, MTurck.1966. Antibiotic susceptibility testing by standard single disc method.Am J. Clin.Pathol. 45:493-496.

BoukefK, HRSouissi, GBalansard. 1982. Contribution to the study of plants used in traditional medicine in Tunisia.16: 260-279.

Burkill HM. 1985. The useful plants of West Tropical Africa. $2^{\text {nd }}$ Edn, vol. 1, Royal Botanic Gardens, Kew, UK, pp 960.

Caceres A, L.MGiron, S.R. Alvarado, MF Torres, 1987.Screening of antimicrobial activity of plants popularly used in Guatemala for the treatment of dermatomucosal diseases. 9:20: 223-237.

Caldwell DR, VerinHartwick-Young R, Meyer SM, Drake MW. 1992. Efficacy and safety of Lodoxamide $0.1 \%$ vs. Cromolyn Sodium $4 \%$ in patients with vernal keratoconjunctivitis. Amer J Ophthalmol, 113: 632- Đ37.

Campos MA, M A Vargas, V Regueiro, CM Llompart, S Albertí, JA Bengoechea.2004. Capsule polysaccharide mediates bacterial resistance to antimicrobial peptides. Infect Immun 72:7107-14.

Ceylan E, DYC Fung. 2004. Antimicrobial activity ofspices. J Rap Meth Automat Microbiol, 12:1-55.

Clinical and Laboratory Standards Institute (CLSI).2007. Performance standards for antimicrobial susceptibility testing; seventeenth information supplement. Wayne 
Pennsylvania: Clinical and Laboratory Standards Institute. CLSI document M100-S17.

DeSantis TZ Jr., P Hugenholtz, K Keller, EL Brodie, N Larsen.2006. NAST: A multiple sequence alignment server for comparative analysis of $16 \mathrm{~S}$ rRNA genes. Nucleic Acids Res. 34: 394-399.

Domenico P, RJSalo, AS Cross, and BAChuna. 1994. Polysaccharide capsule-mediated resistance to opsonophagocytosis in Klebsiellapneumoniae, Infect Immun. 62: 4495-4499.

Duffy C F, R F Power.2001. Antioxidant and antimicrobial properties of some Chinese plant extracts. IntJAntimicrob Agents. 17:527-529.

El -Tarras, A. E., A. F. Shahaby, N.S. Awad.2012. In Vitro Screening for natural oil degrading bacteria and evaluation of their biodegradation potential for hydrocarbon. Afr $\mathrm{J}$ Microbiol Res. 6(49) 7534-7544.

Fode-Vaughan KA, CFWimpee,CCRemsen, MLPCollins.2001.Detection of bacteria in environmental samples by direct PCR without DNA extraction. Biotechniques31, 598-607.

Gao Y, M J van Belkum,M E Stiles. 1999.The outer membrane of Gramnegative bacteria inhibits antibacterial activity of brochocin-C, Appl Environ Microbiol.65: 4329-4333,

Garrity G M, J G Holt. 2001. The road map to the manual, p. 119-166. In G. M. Garrity (ed), Bergey's manual of systematic bacteriology. SpringerVerlag, New York, N.Y.

Gerhardt P, RGE Murray, RN Costllow, EW Nester, WAWood (eds.). 1984. Manual of Methods for General Bacteriology.American Society for Microbiology, Washington, DC, USA.
Goh H, ESoepadm., PChang, UBanerjee, KCChan, JRDeverre, HHadi, SELoke, ANassrulhawq, SLOo, C.ETaylor, WHWong, MZakaria. 1984. In: Seoul, Korea, 20-24 August 1984,_Han, B.H., Han, D.S., Han, Y.N., Woo, W.S. (eds). Vol. 5: 473483.

Gujral, M.L., Varma, D.R. and Sareen, K.N. 1960. Oral contraceptives.Part I. Preliminary observations on the antifertility effect of some indigenous drugs. 48: 46-51.

Hall TA.1999.BioEdit: a user-friendly biologicalsequence alignment editor and analysis programfor Windows 95/98/NT. Nucl.Acids.Symp. Ser. 41:95-98.

Harwood VJ, MBrownell, SWang, JLepo, RDEllender, AAjidahun, KNHellein, EKennedy, XYe, CFlood. 2009. Validation and field testing of libraryindependent microbial source tracking methods in the Gulf of Mexico. Water Res. 43 (19), $4812 \mathrm{e} 4819$.

Hiltner L.1904. UberneueErfahrungen und Probleme auf demGebiet der Bodenbakteriolgie und unterbesonderesBerucksichtigung der Grundugungen und Brauche.ArbDtschLandwirtGesBerl 98:59-78.

Holt J G, N R Krieg, P H ASneath,, J T Staley, STWillims. (eds.). 1994. Bergey's Manual of Determinative Bacteriology, 9th edition. Baltimore: Williams and Wilkins.

JainSP, HSPuri. 1984. Ethnomedical plants of Jaunsar-Bawar Hills, Uttar Pradesh, India. 9:12: 213-222.

Jensen PR, E,Gontang,CMafnas, TJMincer, WFenical. 2005. Culturable marine Actinomycetes diversity from tropical Pacific Ocean sediments. Appl. Environ. Microbiol. 7:1039-1048. 
Jochle W. 1971.Biology and pathology of reproduction in Greek mythology.Contraception. 4(1):1-13.

JohnsonT D. 2007.Pomegranate: Preserving Dental Health. Life Extension Magazine, May, 2007.

Jorgensen J H, MA Pfaller, K C Carroll, G Funke, ML Landry, SS Richter, DW Warnock. 2015. Manual of Clinical Microbiology, $11^{\text {th }}$ Ed., V( 1), ASM Press, Washington, DC. USA

Joseph SB. 2009. Impact of antibiotic resistance in the management of ocular infections: the role of current and future antibiotics. Clin.Ophthalmol. 3:507-521.

Kalemba D, A Kunicka. 2003. Antibacterial and antifungal properties of essential oils. Current Med Chem. 10: 813829.

Kapoor LD. 1990.CRC Press, Boca Raton, Florida.

Kennedy AC.2005. Rhizosphere. In: Sylvia DM, Fuhrmann JJ, Hartel PG, Zuberer DA (eds) Principles and applications of soil microbiology, 2nd edn. Pearson, Prentice Hall, Upper Saddle River, NJ, pp 242-262.

Kloepper JW.2003. A review of mechanisms for plant growth promotion by PGPR. In: Reddy MS, Anandaraj M, Eapen SJ, Sarma YR, Kloepper JW (eds) 6th International PGPR workshop (Abstracts and short papers), 5-10 Oct 2003, Indian Institute of Spices Research, Calicut, India, pp 81-92.

Krieg, NR. 1984. Systematics, P 407-409. In: P. Gerhardt, R.G.E. Murray, R.N. Costllow, E.W.Nester, and W.A.Wood (eds.), Manual of Methods for General Bacteriology. American Society for Microbiology, Washington, DC, USA.

Linzenmeier G. 1958. A simple modification of the Tarozzi anaerobic medium. ZentralblBakteriol Orig. 171(3):192-4.

Lopez P, C Sanchez, R Batlle and C Nerin. 2005. Solid and vapor-phaseantimicrobial activities of six essential oils: susceptibility of selected food-borne bacterial and fungal strains. J Agric Food Chem. 53:6939-6946.

Lynch JM.1990. Introduction: some consequences of microbial rhizosphere competence for plant and soil. In: Lynch JM (ed) The rhizosphere. Wiley, Chichester, pp 110.

Maniatis T, EF Fritsch and JSambrook. 1982. Molecular Coloning: A laboratory manual. Cold Spring Harbor, N.Y., Cold Spring Harbor Laboratory.

Marjorie MC. 1999.Plant products as antimicrobial agents. ClinMicrobiol Rev, 12:564-582,

McDonnell G and A D Russell. 1999. Antiseptics and disinfectants: activity, action, and resistance. Clin.Microbiol. Rev. 12:147-179.

Murray P R, E J Baron, M A Pfaller,F C Tenover and R H Yolken. 1999. Manual of clinical microbiology, 7th ed. ASM Press, Washington,D.C.

NagarajuN, K.NRao. 1990. A survey of plant crude drugs of Rayalaseema, Andhra Pradesh,India. 9:29: 137-158.

NCCLS (National Committee for Clinical Laboratory extracts including phenols, tannins and flavonoids as Standard). 1999. Performance Standards for major active constituents may be responsible for this Antimicrobial Susceptibility Testing, 9 International activities. Supplement. M100-S9, Wayne Pa.

Nikaido H. 1996.Outer membrane, in FC Neidhardt (ed), Escherichia coli and Salmonella typhimurium: Cellular 
and Molecular Biology, Am SocMicrobiol Press, Washington, DC, pp 29-47,

Nilsson WB, RN Paranjype, ADePaola, MS Strom. 2003. Sequence polymorphism of the 16S rRNA gene of Vibrio vulnificus is a possible indicator of strain virulence. J. Clin. Microbiol. 41:442-446.

OECD. 2007. Consensus Document on Safety Information on Transgenic Plants Expressing Bacillus thuringiensis - Derived Insect Control Protein. ENV/JM/MONO(2007)14. Series on Harmonisation of Regulatory Oversight in Biotechnology. http://www.agbios.com/docroot/articl es/07-214-001.pdf.

Panichayupakaranant $\mathrm{P}, \mathrm{S}$ Tewtrakul, S Yuenyongsawad. 2010.Antibacterial, anti-inflammatory and anti-allergic activities of standardized pomegranate rind extract. Food Chemistry 123 (2010) 400-403

RamírezVR, L.JMostacero, A.EGarcia, C.FMejia, PFPelaez, CDMedina, CHMiranda.1988. 6 BancoAgrario Del Peru \&Nacl.Univ.Trujillo, Trujillo, Peru.

Rantakokko-Jalava K, S Nikkari, J Jalava, E Eerola, M Skurnik, O. Meurman, O. Ruuskanen, A Alanen, E Kotilainen, $\mathrm{P}$ Toivanen, P Kotilainen. 2000. Direct amplification of rRNA genes in diagnosis of bacterial infections. $\mathrm{J}$. Clin. Microbiol.38: 32-39.

Russell AD. 1991. Mechanisms of bacterialresistance to non- antibiotics, foodadditives and pharmaceutical preservatives. J ApplBacteriol. 71:191-20.

Sacchi CT, AM Whitney, LW Mayer, R Morey, A Steigerwalt, A Boras, RSWeyant, T Popovic. 2002. Sequencing of $16 \mathrm{~S}$ - rRNA gene: a rapid tool for identification of Bacillus anthracis.Emerg. Infect. Dis. 8:1117-1123.

ShahabyAF.2014. Assessment of Mixed Culture of Actinomyces and Sacchromyces for biodegradation of Complex Mineral Oil hydrocarbon.Intern. J. Currn. Microbiol. Appl. Scien. 3 (4): 401414.

Shahaby AF, AA Alharthi and A E El Tarras. 2015. Potential Bacterial Pathogens of Red Eye Infections and Their Antibiotic Susceptibility Patterns in Taif, KSA. Intern. J. Currn. Microbiol. Appl. Scien. (IJCMAS) 4 (11): 383-393.

ShahabyAF, Abdulla A. Alharthi, Adel E. El Tarras. 2015. Bacteriological Evaluation of Tap Water and Bottled Mineral Water In Taif, Western Saudi Arabia. Intern. J. Currn. Microbiol. Appl. Scien. (IJCMAS) 4 (12): 600615.

Shahaby AF, AA Alharthi, AE El Tarras 2015. Bioremediation of Petroleum Oil by Potential Biosurfactant-Producing Bacteria using Gravimetric Assay. Intern. J. Currn. Microbiol. Appl. Scien. (IJCMAS) 4 (5): 390-403.

Shirato S, HMotoyama. 1966. Fermentation Studies with Streptomyces griseus. II. Synthetic Media for the Production of Streptomycin. ApplMicrobiol. 1966 Sep; 14(5): 706-710. PMCID: PMC 1058400

Siang ST. 1983.Use of combined traditional Chinese and Western medicine in the management of burns. 25: 197-202.

Singh VP, SK Sharma, VSKhare. 1980. Medicinal plants from Ujjain District Madhya Prades. Part II. 1,15: 7-12.

Singh YN. 1986. Traditional medicine in Fiji: Some herbal folk cures used by Fiji Indians. 9:15: 57-88. 
Smith-Palmer A, J Stewart and L Fyfe. 1998. Antimicrobial properties of plant essential oils and essences against five important food-borne pathogens. LettApplMicrobiol. 26:118-122,

SussmanJ I, E J Baron, M J Tenenbaum, M H Kaplan, J Greenspan, RRFacklam, M BTyburski, M A Goldman, B FKanzer and $\mathrm{R} A$ Pizzarello. $1986 . \quad$ Viridans streptococcal endocarditis: clinical, microbiological, and echocardiographic correlations. J. Infect. Dis. 154:597-603.

Tewelde T, BGetnet, GYeshigeta, BSisay, SMuthupandian. 2013. Bacterial Profile and Antimicrobial Susceptibility Pattern of External Ocular Infections in Jimma University Specialized Hospital, Southwest Ethiopia. Am. J. Infect.
Dis. Microbiol. 1(1): 13-20.

Tortoli E. 2003. Impact of genotypic studies on mycobacterial taxonomy: the new mycobacteria of the 1990s. Clin.Microbiol.Rev. 16:319-354.

Woese C R, E Stackebrandt, T J Macke and G E Fox. 1985. A phylogenetic definition of the major eubacterial taxa. Syst. Appl. Microbiol. 6:143151.

Woese C R, E Stackebrandt, T J Macke and $\mathrm{G}$ E Fox. 1985. A phylogenetic definition of the major eubacterial taxa. Syst. Appl. Microbiol. 6:143151.

Wren RC. 1988. The C.W. Daniel Company, Essex.

Zhicen, L. 1987. Science Press, Beijing, People's Republic of China, pp. 7576.

\section{How to cite this article:}

Ahmad F. Shahaby, Abdulla A. Alharthi and Adel E. El Tarras. 2016. Screening of Natural Bacterial Flora of Pomegranate Roots (Punica granatum L.) and their Antibiotic Activity in Taif, Saudi Arabia. Int.J.Curr.Microbiol.App.Sci. 5(2): 1-16. doi: http://dx.doi.org/10.20546/ijcmas.2016.502.001 